\title{
Hubungan antara Kepribadian dan Motivasi terhadap Intensi Santri Putri Pondok Pesantren Bahrul 'Ulum Tambakberas Jombang
}

\author{
Oleh: Asrori Umar \\ STAI Bahrul 'Ulum Tambakberas Jombang
}

\begin{abstract}
Abstrak
Intensi kewirausahaan dapat diartikan sebagai proses pencarian informasi yang dapat digunakan untuk mencapai tujuan pembentukan suatu usaha. Intensi kewirausahaan dipengaruhi oleh berbagai factor diantaranya kepribadian, factor lingkungan dan motivasi. Dalam penelitian ini ingin diketahui seberapa besar pengaruh dan kontribusi kepribadian, factor lingkungan dan motivasi terhadap intensi kwirausahaan mahasiswa.

Dalam penelitian ini digunakan analisis regresi komponen utama karena dugaan awal analisis dengan menggunakan regresi ganda metode kuadrat terkecil ditemukan kasus multikolinieritas walaupun pada uji serentak koefisien regresi gandanya signifikan dengan persamaan regresinya :

$$
\hat{Y}=0,026+0,062 X_{1}+0,22 X_{2}+0,362 X_{3}
$$

Dari hasil analisis menunjukkan bahwa kepribadian dan motivasi memberikan pengaruh hubungan dan kontribusi yang signifikan terhadap intensi kewirausahaan mahasiswa, kecuali pada faktor lingkungan yang tidak memberikan pengaruh yang signifikan. Tingkat sensitifitas terbesar intensi kewirausahaan mahasiswa terdapat pada kepribadian, yaitu sebesar 1,042 yang dapat diinterpretasikan bahwa bila kepribadian meningkat $1 \%$ akan meningkatkan intensi kewirausahaan santri putri (Y) sebesar $1,042 \%$.
\end{abstract}

Kata kunci : Intensi Kewirausahaan, Regresi Komponen Utama

\section{PENDAHULUAN}

\section{Latar Belakang}

Pendidikan kewirausahaan selama ini telah dipertimbangkan sebagai salah satu faktor penting untuk menumbuhkan dan mengembangkan hasrat, jiwa dan perilaku berwirausaha di kalangan generasi muda (Kourilsky dan Walstad, 1998). Beberapa penelitian sebelumnya menyebutkan bahwa keinginan berwirausaha para siswa merupakan sumber bagi lahirnya wirausaha-wirausaha masa depan (Gorman et al., 1997). Sikap, perilaku dan pengetahuan mereka tentang kewirausahaan akan membentuk kecenderungan mereka untuk membuka usaha-usaha baru di masa mendatang. Kecenderungan mereka tersebut akan mengarah pada terbentuknya intensi kewirausahaan 
dalam diri mereka, dimana intensi kewirausahaan merupakan komponen dalam diri individu yang mengacu pada keinginan untuk melakukan tingkah laku kewirausahaan( Fishbein \& Ajzen 1975) .

Seseorang dengan intensi untuk memulai usaha akan memiliki kesiapan dan kemajuan yang lebih baik dalam usaha yang dijalankan dibandingkan seseorang tanpa intensi untuk memulai usaha. Seperti yang dinyatakan oleh Krueger dan Carsrud (1993), intensi telah terbukti menjadi prediktor yang terbaik bagi perilaku kewirausahaan.

Secara garis besar intensi kewirausahaan dipengaruhi oleh tiga hal secara berbeda-beda: karakteristik kepribadian; karakteristik lingkungan dan motivasi. Beberapa peneliti terdahulu membuktikan bahwa faktor kepribadian seperti kebutuhan akan prestasi (McClelland, 1961) dan efikasi diri (Gilles dan Rea, 1999) merupakan prediktor signifikan intensi kewirausahaan. Kristiansen (2001;2002a) menyebut bahwa faktor lingkungan seperti hubungan sosial, infrastruktur fisik dan institusional serta faktor budaya dapat mempengaruhi intensi kewirausahaan. Hal yang tak kalah penting dalam menumbuhkan intensi kewirausahaan adalah motivasi. Sebagian besar entrepreneur dimotivasi oleh keinginan untuk menentukan nasibnya sendiri.

Penelitian ini bertujuan untuk mengkaji hubungan antara intensi kewirausahaan dengan kepribadian, faktor lingkungan dan motivasi.

Penelitian dibatasi pada peubah kepribadian yang meliputi: kebutuhan akan prestasi dan efikasi diri; peubah faktor lingkungan, yang meliputi tiga elemen kontekstual: akses kepada modal, informasi dan jaringan sosial; dan peubah motivasi serta peubah intensi kewirausahaan.

\section{Perumusan Masalah}

Sesuai dengan hubungan yang telah dibatasi tersebut, maka rumusan masalahnya adalah sebagai berikut:

1. Seberapa besar pengaruh dan kontribusi kepribadian mahasiswa memberikan perubahan terhadap intensi kewirausahaan santri putri?

2. Seberapa besar pengaruh dan kontribusi faktor lingkungan memberikan perubahan terhadap intensi kewirausahaan santri putri? 
3. Seberapa besar pengaruh dan kontribusi motivasi memberikan perubahan terhadap intensi kewirausahaan santri putri?

4. Seberapa besar pengaruh dan kontribusi kepribadian, faktor lingkungan dan motivasi memberikan perubahan secara simultan terhadap intensi kewirausahaan santri putri?

\section{KERANGKA TEORITIK DAN HIPOTESIS}

\section{Intensi Kewirausahaan Santri Putri}

Intensi kewirausahaan dapat diartikan sebagai proses pencarian informasi yang dapat digunakan untuk mencapai tujuan pembentukan suatu usaha (Katz dan Gartner, 1988). Intensi adalah bagian penting teori aksi beralasan (Theory of reasoned action) dari Fishbein \& Ajzen (1975). Intensi merupakan prediktor sukses dari perilaku karena ia menjembatani sikap dan perilaku. Intensi merupakan sebuah istilah yang terkait dengan tindakan dan merupakan unsur yang penting dalam sejumlah tindakan, yang menunjukan pada keadaan pikiran seseorang yang diarahkan untuk melakukan sesuatu tindakan, yang senyatanya dapat atau tidak dapat dilakukan dan diarahkan entah pada tindakan sekarang atau pada tindakan yang akan datang. Intensi memainkan peranan yang khas dalam mengarahkan tindakan, yakni menghubungkan antara pertimbangan yang mendalam yang diyakini dan diinginkan oleh seseorang dengan tindakan tertentu. Berdasarkan uraian di atas dapat disimpulkan bahwa intensi adalah kesungguhan niat seseorang untuk melakukan perbuatan atau memunculkan suatu perilaku tertentu.

\section{Indikator-indikator Intensi Kewirausahaan}

Bentuk indicator intensi kewirausahaan adalah minat dan keinginan serta ketrampilan santri putri terhadap wirausaha. 


\section{Kepribadian}

\section{Pengertian-Pengertian dan Teori Dasar Kepribadian}

Kepribadian diartikan sebagai karateristik seseorang yang melikat dan memberikan ciri terhadap penampilan dan aktifitas geraknya terhadap penilaian orang lain. Yang termasuk kedalam kepribadian adalah kebutuhan akan prestasi dan efikasi diri.

Bandura (1977: 12) mendefinisikan efikasi diri sebagai kepercayaan seseorang atas kemampuan dirinya untuk menyelesaikan suatu pekerjaan. Atau dengan kata lain, kondisi motivasi seseorang yang lebih didasarkan pada apa yang mereka percaya daripada apa yang secara objektif benar. Persepsi pribadi seperti ini memegang peranan penting dalam pengembangan intensi seseorang. Senada dengan hal tersebut, Cromie (2000:67) menjelaskan bahwa efikasi diri mempengaruhi kepercayaan seseorang pada tercapai atau tidaknya tujuan yang sudah ditetapkan. Factor kepribadian seperti kebutuhan akan prestasi dan efikasi diri (Indarti, 2004:2) merupakan predictor signifikan intensi kewirausahaan.

\section{Indikator-indikator kepribadian}

Indicator-indikator yang membentuk kepribadian kewirausahaan meliputi kebutuhan akan prestasi, afeksi dan berani mengambil resiko menurut McClelland (1976)

\section{Lingkungan Kewirausahaan}

\section{Pengertian-Pengertian dan Teori Dasar lingkungan Kewirausahaan}

Lingkungan kewirausahaan diartikan sebagai ruang lingkup dan dimensi yang menciptakan suasana kewiraushaan seseorang. Biasanya merupakan lokasi atau tempat yang mendukung kegiatan kewirausahaan. Tiga faktor lingkungan yang dipercaya mempengaruhi wirausaha yaitu akses mereka kepada modal, informasi dan kualitas jaringan sosial yang dimiliki, yang kemudian disebut kesiapan instrumen (Indarti, 2004). Kristiansen $(2001 ; 2002 a)$ menyebut bahwa faktor lingkungan seperti hubungan sosial, infrastruktur fisik dan institusional serta faktor budaya dapat mempengaruhi intensi kewirausahaan. 


\section{Indikator-indikator Lingkungan Kewirausahaan}

Yang termasuk indicator lingkungan untuk membentuk intense kewirausahaan adalah : Akses kepada modal, informasi dan jaringan social oleh Indarti (2004).

\section{Motivasi}

\section{Pengertian-pengertian dan Teori Dasar Motivasi}

Istilah motivasi merujuk pada kondisi dasar yang mendorong tindakan. Teori Harapan dan Motivasi dari Vroom ini memiliki tiga asumsi pokok, yaitu:

1). Suatu perilaku tertentu akan menghasilkan hasil tertentu (Outcome expectacy)

2). Hasil tersebut memiliki nilai positif baginya (Valence)

3). Hasil tersebut dapat dicapai dengan usaha yang dilakukan seseorang (Effort Expecxtacy).

Marx \& Tombouch mengumpamakan motivasi aebagai bahan bakar dalam beroperasinya mesin gasoline (Syah, Muhibbin. 2002). Artinya motivasi sebagai penggerak atau pendorong bagi terbentuknya sebuah upaya tertentu yang dilakukan manusia untuk mencapai tujuannya.

\section{Indikator-indikator Motivasi.}

Motivasi memiliki fungsi indikator antara lain :

- Mendorong timbulnya kelakuan atau suatu perbuatan

- Mengarahkan perbuatan pada pencapaian tujuan yang diinginkan

- Menggerakan tingkah laku seseorang.

\section{Hasil penelitian yang Relevan}

Hasil penelitian Indarti (2008) menunjukkan bahwa kepribadian mahasiswa yang meliputi sub variable kemauan untuk berprestasi dan efikasi diri mahasiswa Indonesia memberikan pengaruh terhadap intensi kewirausahaan mahasiswa. Hal yang sama juga ditunjukan pada lingkungan kewirausahaan, dimana kesiapan instrument memberikan pengaruh yang nyata terhadap intense kewirausahaan mahasiswa. Namun dalan 
penelitian ini tidak memasukkan motivasi sebagai komponen yang juga memberikan pengaruhnya terhadap intense kewirausahaan mahasiswa.

Yohnson (2003) dalam penelitiannya menyatakan bahwa factor motivasi memberikan pengaruh yang dominan terhadap kewiraushaan mahasiswa. Dari hasil penelitian yang diadakan pada alumni Universitas Kristen Petra memperlihatkan bahwa factor yang paling dominan memotivasi sarjana menjadi wirausahawan adalah faktor kesempatan, faktor kebebasan dan faktor kepuasan hidup. Ketiga factor itulah yang membuat mereka menjadi wirausahawan. Namun dalam penelitian ini hanya menekankan pada motivasi dan tidak menjelaskan secara konkret factor lain yang juga menjadi factor yang mempengaruhi intense kewirausahaan mahasiswa.

Berdasarkan penelitian yang telah dilakukan oleh Indarti (2008) dan Johnson (2003) makan perlu dikembangkan penggabungan dari variable-varibel yang mempengaruhi intense kewirausahaan mahasiswa. Peneliti ingin menambahkan variable yang telah dilakukan Indarti (2008) dengan variable yang telah dilakukan oleh Johnson sehingga ada tiga variable yang akan mempengaruhi intense kewiraushaan mahasiswa, yaitu kepribadian, lingkungan wirausaha dan motivasi.

\section{Kerangka berpikir}

\section{Hubungan kepribadian dengan intensi kewirausahaan santri putri}

Kebutuhan akan prestasi sebagai salah satu karakteristik kepribadian seseorang yang akan mendorong seseorang untuk memiliki intensi kewirausahaan. Seseorang dengan tingkat kebutuhan akan prestasi yang tinggi kurang dapat menerima kegagalan daripada mereka dengan kebutuhan akan prestasi rendah. Dengan kata lain, kebutuhan akan prestasi berpengaruh pada atribut kesuksesan dan kegagalan. Sejalan dengan hal tersebut bahwa kebutuhan akan prestasi berpengaruh besar dalam tingkat kesuksesan seorang wirausaha. Lebih spesifik, kebutuhan akan prestasi juga dapat mendorong kemampuan pengambilan keputusan dan kecenderungan untuk mengambil resiko seorang wirausaha. Semakin tinggi kebutuhan akan prestasi seorang wirausaha, semakin banyak keputusan tepat yang akan diambil. Wirausaha dengan kebutuhan akan prestasi tinggi 
adalah pengambil resiko yang moderat dan menyukai hal-hal yang menyediakan balikan yang tepat dan cepat.

Berdasarkan uraian di atas dapat disimpulkan bahwa kepribadian memberikan pengaruh terhadap intensi kewirausahaan, dimana komponen pembentuk kepribadian kewirausahaan mahasiswa meliputi; kemauan berprestasi, efikasi diri dan berani mengambil resiko.

\section{Hubungan factor lingkungan dengan intensi santri putri}

Tiga faktor lingkungan yang dipercaya mempengaruhi wirausaha yaitu akses mereka kepada modal, informasi dan kualitas jaringan sosial yang dimiliki. Kesulitan dalam mendapatkan akses modal, skema kredit dan kendala sistem keuangan dipandang sebagai hambatan utama dalam kesuksesan usaha menurut calon-calon wirausaha di negara-negara berkembang, akses kepada modal menjadi salah satu penentu kesuksesan suatu usaha.

Keinginan yang kuat untuk memperoleh informasi adalah salah satu karakter utama seorang wirausaha. Pencarian informasi mengacu pada frekuensi kontak yang dibuat oleh seseorang dengan berbagai sumber informasi. Hasil dari aktivitas tersebut sering tergantung pada ketersediaan informasi, baik melalui usaha sendiri atau sebagai bagian dari sumber daya sosial dan jaringan. Ketersediaan informasi baru akan tergantung pada karakteristik seseorang, seperti tingkat pendidikan dan kualitas infrastruktur, meliputi cakupan media dan sistem telekomunikasi.

Jaringan sosial mempengaruhi intense kewirausahaan. Bagi wirausaha, jaringan merupakan alat mengurangi resiko dan biaya transaksi serta memperbaiki akses terhadap ide-ide bisnis, informasi dan modal.

\section{Hubungan motivasi dengan intense kewirausahaan santri putri}

Motivasi untuk melakukan kegiatan kewirausahaan tidak terlepas dari motif mahasiswa yang bersangkutan, dan motif adalah daya upaya yang mendorong seseorang untuk melakukan sesuatu. Motivasi memiliki fungsi antara lain :

a. Mendorong timbulnya kelakuan atau suatu perbuatan 
b. Mengarahkan perbuatan pada pencapaian tujuan yang diinginkan

c. Menggerakan tingkah laku seseorang.

\section{Hubungan kepribadian, factor lingkungan dan Motivasi secara simultan dengan}

Intensi Kewirausahaan santri putri.

Berdasakan uraian teori diatas dapatlah dibuat konsep penelitian bahwa intense kewirausahaan mahasiswa dipengaruhi oleh factor kepribadian, factor lingkungan dan motivasi sehingga fungsi hubungan dari masing-masing factor tersebut dapat membentuk fungsi persamaan regresi ganda.

\section{Hipotesis Penelitian}

Berdasarkan kerangka teori dan kerangka berpikir yang telah dikaji sebelumnya maka dapat dirumuskan hipotesis penelitian sebagai berikut :,

1. $\mathrm{H}_{1}$ : Ada pengaruh positif dan signifikan kepribadian terhadap intensi Kewirausahaan santri putri.

2. $\mathrm{H}_{1}$ : Ada pengaruh positif dan signifikan faktor lingkungan terhadap intensi kewirausahaan santri putri.

3. $\mathrm{H}_{1}$ : Ada pengaruh positif dan signifikan motivasi terhadap intensi kewirausahaan santri putri

4. $\mathrm{H}_{1}$ : Terdapat hubungan yang positif dan signifikan secara simultan antara kepribadian, faktor lingkungan dan motivasi terhadap intensi santri putri.

\section{METODOLOGI PENELITIAN}

\section{Tujuan Penelitian}

Penelitian ini bertujuan untuk mengetahui hubungan antara kepribadian, factor lingkungan dan motivasi secara simultan dengan intensi kewirausahaan santri putri. 


\section{Tempat dan Waktu Penelitian}

Penelitian ini dilaksanakan di pondok pesantren Bahrul 'Ulum Tambakberas Jombang Jawa Timur, dengan waktu penelitian mulai dari tanggal 4 Mei 2011 sampai dengan tanggal 9 Desember 2011.

\section{Metode dan Disain Penelitia}

Metode Penelitian, metode survey dengan teknik korelasional dengan menggunkan analisis regresi. Disain penelitian ini meliputi tahapan analisis data penelitian yang dilakukan, Meliputi Rancangan Analisis, Analisa Deskriptif dan analisis Inferensial

\section{Populasi dan Teknik Pengambilan Sampel}

Populasi target dalam penelitian ini adalah seluruh santri putri Pondok Pesantren Bahrul Ulum Jombang, sedangkan populasi terjangkau adalah santri putri sebanyak 100 orang.

Teknik pengambilan sampel menggunakan teknik sampel acak terstratifikasi (stratified random sampling), yakni mengambil sampel secara acak proporsional dari masing-masing kelompok yang ada di pondok pesantren Bahrul Ulum. Sedangkan penentuan jumlah sampel menggunakan rumusan (Bungin, 2009), sebagai berikut:

$$
n=\frac{N}{N(d) 2+1}
$$

Keterangan:

$\mathrm{n}=$ Ukuran sampel

$\mathrm{N}=$ Ukuran populasi

$\mathrm{d}=$ Nilai presisi (ditentukan, yaitu 99,5\% atau a $=0,05$ )

Sehingga didapatkan data sampel sebesar 30 orang.

\section{Analisis Data}

Analisis data yang digunakan adalah analisis regresi ganda.

1. Model Analisis 


$$
Y=\beta_{0}+\beta_{1} X_{1}+\beta_{2} X_{2}+\beta_{3} X_{3}+\varepsilon
$$

Dimana :

$\mathrm{Y} \quad=$ Intensi Kewirausahaan mahasiswa

$\mathrm{X} 1=$ Kepribadian Mahasiswa

$\mathrm{X} 2=$ Efikasi Diri Mahasiswa

$\mathrm{X} 3=$ Motivasi

$\beta_{0} \quad=$ Intercept, yaitu titik potong antara garis regresi dengan sumbu tegak Y atau nilai $\mathrm{Y}$ jika semua variable bebas $\mathrm{X}_{\mathrm{i}}$ bernilai nol.

$\mathrm{B}_{\mathrm{j}} \quad=$ Slope, menyatakan besarnya penambahan atau pengurangan dalam variable $Y$ untuk setiap penambahan satu unit $X_{i},(i=1,2,3)$ untuk $\mathrm{j}=1,2,3$

$\varepsilon \quad=$ residual, yaitu selisih nilai respon yang sesungguhnya dengan nilai taksiran yang diperoleh dari model.

\section{Tahap Analisis}

a. Analisis Regresi berganda dengan metode kuadrat terkecil klasik (Ordinary Least Square) untuk mengetahui factor-faktor apa saja yang mempengaruhi intensi kewirausahaan santri putrid pondok pesantren Bahrul 'Ulum Jombang sebagai penduga awal.

b. Uji asumsi-asumsi agar diperoleh model yang tak bias, konsisten dan efisien.

Asumsi-asumsi tersebut diantaranya:

1) Multikolinearitas

Pada tahap ini dilihat nilai $\mathrm{R}^{2}$ (koefisien determinasi) dan nilai VIF (Variance inflation Factor) serta dilakukan uji individu terhadap parameter model. Apabila terjadi kasus multikolinieritas maka diselesaikan dengan regresi Stepwise (Stepwise regression). 
2) Heterokedastisitas

Pada tahap ini, untuk mengetahuinya digunakan uji Glejser. Apabila ditemukan kasus heteroskedastisitas maka solusinya adalah melakukan transformasi terhadap variable.

3) Autokorelasi

Pada tahap ini uji yang digunakan adalah uji Durbin Watson, namun selain itu juga dilihat dari plot ACF. Bila $95 \%$ nilai-nilai ACF tidak melebihi batas \pm $(1,96 / \sqrt{ } \mathrm{n})$, maka asumsi tidak ada autokorelasi terpenuhi.

4) Berdistribusi Normal

Untuk memeriksa kenormalan dapat digunakan uji Kolmogorov-Smirnov yaitu dengan membandingkan $\mathrm{P}_{\text {value }}$ statistic Kolmogorov-Smirnov dengan $\alpha=0,05$.

Setelah diperoleh model regresi yang sudah memenuhi beberapa asumsi klasik yang telah ditetapkan, maka dari model akhir tersebut dilakukan analisis dan kemudian dibuat kesimpulan.

\section{HASIL PENELITIAN}

\section{Pengujian Hipotesis}

\section{Kepribadian Berpengaruh secara signifikan terhadap Intensi Kewirausahaan Santri Putri}

Berdasarkan hasil analisis regresi komponen utama bahwa besarnya pengaruh antara variable kepribadian (X1) dalam bentuk skor baku Z1 terhadap intense kewirausahaan santri putri $(\mathrm{Y})$ yang dihitung dengan koefisien korelasi adalah 0,725 atau $\left(\mathbf{r}_{\text {Z1.y }}=0,725\right)$. Hal ini menunjukkan pengaruh yang sangat kuat antara kepribadian terhadap intense kewirausahaan santri putri. Sedangkan tingkat signifikansi koefisien korelasi satu sisi ( 1 -tailed) dengan $\alpha=0,05$, maka pengaruh antara kepribadian terhadap intense kewirausahaan santri putri adalah signifikan. Ini berarti gagal terima Ho, yang berarti menerima $\mathrm{H} 1$ yang menyatakan secara statistic bahwa: $H_{1}=\rho_{y .1}>0$

Pada table ANOVA atau uji $\mathrm{F}$, ternyata didapat $\mathrm{F}$ hitung adalah 12,5 dimana 
$\mathrm{P}-$ value (bernilai 0,001$)<$ dari $\alpha=0,05$, maka model regresi dapat dipakai untuk memprediksi intense kewirausahaan santri putri. Ini berarti gagal menerima Ho, dan menerima H1, yang secara statistic menyatakan bahwa:

$H_{1}: \beta_{j} \neq 0, \operatorname{dim}$ ana $j=1,2,3$

Persamaan regresinya adalah sebagai berikut:

$$
\hat{Y}=0,036+0,1678 X_{1}
$$

Dimana :

X1 : kepribadian

$\mathrm{Y} \quad$ : intense kewirausahaan santri putri

Konstanta 0,036 menyatakan bahwa jika tidak ada kenaikan nilai dari variable kepribadian (X1), maka nilai intense kewirausahaan santri putri adalah 0,036. Koefisien regresi sebesar 0,1678 menyatakan bahwa setiap penambahan (karena tanda +) satu skor atau nilai kepribadian akan memberikan peningkatan sebesar 0,1678.

\section{Fakltor Lingkungan berpengaruh secara Signifikan terhadap Intensi Kewirausahaan Santri Putri}

Berdasarkan hasil analisis regresi komponen utama bahwa besarnya pengaruh antara variable factor lingkungan (X2) dalam bentuk skor baku Z2 terhadap intense kewirausahaan santri putri (Y) yang dihitung dengan koefisien korelasi adalah 0,233 atau $\left(\mathbf{r}_{\mathrm{Z} 2 . \mathrm{y}}=0,233\right)$. Hal ini menunjukkan pengaruh yang rendah antara kepribadian terhadap intense kewirausahaan santri putri. Sedangkan tingkat signifikansi koefisien korelasi satu sisi $(1$-tailed) $\mathrm{P}$-Value $=0,108$ lebih besar dari $\alpha$ $=0,05$, maka pengaruh antara kepribadian terhadap intense kewirausahaan santri putri adalah tidak signifikan. Ini berarti Ho diterima yang secara statistic bahwa: $H_{0}=\rho_{y .2} \leq 0$

Pada table ANOVA atau uji $\mathrm{F}$, ternyata didapat $\mathrm{F}$ hitung adalah 12,5 dimana 
$\mathrm{P}-$ value (bernilai 0,001$)<$ dari $\alpha=0,05$, maka model regresi dapat dipakai untuk memprediksi intense kewirausahaan santri putri. Ini berarti gagal terima Ho, dan menerima $\mathrm{H} 1$, yang secara statistic menyatakan bahwa:

$H_{1}: \beta_{j} \neq 0, \operatorname{dim}$ ana $j=1,2,3$

Persamaan regresinya adalah sebagai berikut:

$$
\hat{Y}=0,036+0,2218 X_{2}
$$

Dimana :

$\mathrm{X} 2$ : factor lingkungan

$\mathrm{Y} \quad$ : intense kewirausahaan santri putri

Konstanta 0,036 menyatakan bahwa jika tidak ada kenaikan nilai dari variable kepribadian (X1), maka nilai intense kewirausahaan santri putri adalah 0,036. Koefisien regresi sebesar 0,2218 menyatakan bahwa setiap penambahan (karena tanda +) satu skor atau nilai kepribadian akan memberikan peningkatan sebesar 0,2218.

Pada table 4.8 di atas terlihat bahwa koefisien regresi kepribadian dalam bentuk skor baku Z2 memberikan pengaruh yang signifikan terhadap intense kewirausahaan santri putri yang ditunjukkan nilai t-hitungnya $(=6,349)>$ dari nilai ttabel $(=1,701)$ pada taraf signifikan $\alpha=0,05$.

Jadi dapat disimpulkan bahwa factor lingkungan tidak berpengaruh secara signifikan terhadap intense kewirausahaan santri putri.

\section{Motivasi berpengaruh secara Signifikan terhadap Intensi Kewirausahaan Santri Putri}

Berdasarkan hasil analisis regresi komponen utama bahwa besarnya pengaruh antara variable factor lingkungan (X3) dalam bentuk skor baku Z3 terhadap intense kewirausahaan santri putri $(\mathrm{Y})$ yang dihitung dengan koefisien korelasi adalah 0,440 atau $\left(\mathbf{r}_{\mathrm{Z} 3 . \mathrm{y}}=0,440\right)$. Hal ini menunjukkan pengaruh antara kepribadian terhadap intense kewirausahaan santri putri. Sedangkan tingkat signifikansi koefisien korelasi 
satu sisi $(1$-tailed) dengan $\mathrm{P}$-value $=0,007<\alpha=0,05$, maka pengaruh antara kepribadian terhadap intense kewirausahaan santri putri adalah signifikan.

Ini berarti gagal tolak Ho, yang berarti menerima $\mathrm{H} 1$ yang menyatakan secara statistic bahwa: $H_{1}=\rho_{y .3}>0$

Pada table ANOVA atau uji $\mathrm{F}$, ternyata didapat $\mathrm{F}$ hitung adalah 12,5 dimana $\mathrm{P}-$ value (bernilai 0,001 ) $<$ dari $\alpha=0,05$, maka model regresi dapat dipakai untuk memprediksi intense kewirausahaan santri putri. Ini berarti gagal terima Ho, dan menerima H1, yang secara statistic menyatakan bahwa:

$H_{1}: \beta_{j} \neq 0, \operatorname{dim}$ ana $j=1,2,3$

Persamaan regresinya adalah sebagai berikut:

$$
\hat{Y}=0,036+0,361 X_{3}
$$

Dimana :

X3 : motivasi

$\mathrm{Y} \quad$ : intense kewirausahaan santri

Konstanta 0,036 menyatakan bahwa jika tidak ada kenaikan nilai dari variable kepribadian (X1), maka nilai intense kewirausahaan santri putri adalah 0,036 Koefisien regresi sebesar 0,361 menyatakan bahwa setiap penambahan (karena tanda +) satu skor atau nilai kepribadian akan memberikan peningkatan sebesar 0,361. Pada table 4.8 di atas terlihat bahwa koefisien regresi kepribadian dalam bentuk skor baku Z2 memberikan pengaruh yang signifikan terhadap intensi kewirausahaan santri putri yang ditunjukkan nilai t-hitungnya $(=6,489)>$ dari nilai t-tabel $(=1,701)$ pada taraf signifikan $\alpha=0,05$

Jadi terbukti bahwa motivasi berpengaruh secara signifikan terhadap intense kewirausahaan santri. 


\section{Kepribadian, factor lingkungan dan Motivasi secara Simultan berpengaruh Signifikan terhadap Intensi Kewirausahaan Santri Putri}

Berdasarkan hasil analisis regresi komponen utama bahwa besarnya pengaruh secara simultan antara kepribadian (X1), variable factor lingkungan (X2) dan motivasi (X3) terhadap intense kewirausahaan santri putri (Y) yang dihitung dengan koefisien korelasi adalah 0,555 atau $\left(\mathbf{r}_{\text {y.123 }}=0,555\right)$. Hal ini menunjukkan pengaruh yang sangat kuat antara kepribadian terhadap intense kewirausahaan santri putri. Sedangkan tingkat signifikansi koefisien korelasi satu sisi $(1-$ tailed $) \mathrm{P}-\mathrm{Value}=$ $0,00<\alpha=0,05$, maka pengaruh antara kepribadian terhadap intense kewirausahaan santri putri adalah signifikan.

Ini berarti gagal tolak Ho, yang berarti menerima $\mathrm{H} 1$ yang menyatakan secara statistic bahwa: $H_{1}=\rho_{y .123}>0$

Pada table ANOVA atau uji F, ternyata didapat $\mathrm{F}$ hitung adalah 12,5 dimana P-value (bernilai 0,001$)<$ dari $\alpha=0,05$, maka model regresi dapat dipakai untuk memprediksi intense kewirausahaan santri putri. Ini berarti gagal terima Ho, dan menerima $\mathrm{H} 1$, yang secara statistic menyatakan bahwa:

$$
H_{1}: \beta_{j} \neq 0, \operatorname{dim} \text { ana } j=1,2,3
$$

Persamaan regresinya adalah sebagai berikut:

$$
\hat{Y}=0,036+0,1678 X_{1}+0,2218 X_{2}+0,3612 X_{3}
$$

Dimana :

$\mathrm{X} 1$ : kepribadian

$\mathrm{X} 2$ : factor lingkungan

$\mathrm{X} 3$ : motivasi

$\mathrm{Y} \quad$ : intense kewirausahaan santri putri

Konstanta 0,036 menyatakan bahwa jika tidak ada kenaikan nilai dari variable kepribadian (X1), maka nilai intense kewirausahaan santri putri adalah 0,036. Koefisien regresi sebesar 0,361 menyatakan bahwa setiap penambahan (karena tanda 
+) satu skor atau nilai kepribadian akan memberikan peningkatan sebesar 0,361, nilai factor lingkungan sebesar 0,2218 dan nilai motivasi sebesar 0,3612.

\section{Tingkat Responsi (elastisitas)}

Untuk mengetahui sejauh mana tingkat response (sensitivitas) dari variable takbebas terhadap perubahan dalam variable bebas dari persamaan regresi dapat dihitung elastisitas rata-rata variable tak bebas terhadap setiap variable bebas, melalui rumus ; $E_{i}=\frac{\partial Y}{\partial X_{i}} \cdot \frac{\bar{X}_{i}}{Y}=b_{i}=\left(\frac{\bar{X}_{i}}{Y}\right)$, dimana hasil analisisnya pada table berikut:

Tabel 1. Elastisitas Intensi Kewirausahaan mahsiswa (Y) atas Variabel $\left(\mathrm{X}_{\mathrm{i}}\right)$

\begin{tabular}{|l|l|l|l|l|}
\hline Variabel $(\mathrm{Xi})$ & Koefisien Regresi $\left(\mathrm{b}_{\mathrm{i}}\right)$ & Nilai rata-rata & Elastisitas & Peringkat \\
\hline $\mathrm{X}_{1}$ & 0,1678 & 2,557 & 1,0134 & 1 \\
\hline $\mathrm{X}_{2}$ & 0,2218 & 1,389 & 0,5496 & 2 \\
\hline $\mathrm{X}_{3}$ & 0,3621 & 0,7198 & 0,2857 & 3 \\
\hline
\end{tabular}

Dari table di atas terlihat bahwa elastisitas terbesar pada variable kepribadian $\left(\mathrm{X}_{1}\right)$, yang menunjukkan bahwa variable $\mathrm{Y}$ lebih sensitive pada variable kepribadian $\left(\mathrm{X}_{1}\right)$. Koefisien elastisitas untuk variable kepribadian $\left(\mathrm{X}_{1}\right)$ adalah 1,042 yang dapat diinterpretasikan bahwa bila kepribadian meningkat $1 \%$ akan meningkatkan intensi kewirausahaan santri putri (Y) sebasar 1,042\%.

\section{Pembahasan}

Berdasarkan analisis regresi komponen utama sehingga didapatkan persamaan regresi dengan ketiga variable bebasnya signifikan terhadap variable terikat dengan persamaan regresi sebagai berikut:

Dari persamaan regresi diatas terlihat bahwa koefisien regresi variable bebas bernilai positif yang memberikan hubungan yang positif dengan variable terikat, artinya semakin tinggi nilai variable bebas akan diikuti dengan semakin tinggi pula nilai variable terikatnya. Hal ini berarti variable bebas kepribadian, factor lingkungan dan motivasi 
memiliki hubungan yang erat dan berarah postif dengan variable terikat intensi kewirausahaan santri putri, dimana semakin tinggi kepribadian, factor lingkungan dan motivasi akan ditunjukkan semakin tinggi pula intensi kewirausahaan santri putri. Sejalan dengan pendapat McClelland (1961) yang menyatakan bahwa faktor kepribadian seperti kebutuhan akan prestasi dan efikasi diri memberikan pengaruh yang signifikan terhadap intensi kewirausahaan. Kristiansen (2001;2002a) menambahkan bahwa faktor lingkungan seperti hubungan sosial, infrastruktur fisik dan institusional serta faktor budaya dapat mempengaruhi intensi kewirausahaan. Factor kepribadian seperti kebutuhan akan prestasi, efikasi diri dan motivasi merupakan predictor signifikan intensi kewirausahaan (Indarti, 2004).

Tingkat sensitifitas (response) dari variable takbebas $\mathrm{Y}$ terhadap variable bebas $\mathrm{X}$ terlihat bahwa elastisitas terbesar pada variable kepribadian, dimana variable intensi kewirausahaan santri putri lebih sensitive pada variable kepribadian (X1) dengan koefisien elastisitas sebesar 1,042 \%. McClelland (1971:109) menegaskan kepribadian seseorang yang meliputi kebutuhan akan prestasi dan efikasi sebagai karakteristik kepribadian seseorang merupakan pendorong utama seseorang untuk memiliki intensi kewirausahaan. Bandura (1977) menambahkan bahwa kepribadian sebagai kepercayaan seseorang atas kemampuan dirinya untuk memilki intensi kewirausahaan.

\section{KESIMPULAN, IMPLIKASI DAN SARAN}

\section{Kesimpulan}

Berdasarkan analisis data dengan menggunakan regersi komponen utama terhadap hubungan antara kepribadian, faktor lingkungan dan motivasi terhadap intensi kewirausahaan santri putri diperoleh hasil sebagai berikut:

1. Terdapat hubungan yang signifikan secara parsial antara kepribadian terhadap intensi kewirausahaan santri putri dengan nilai korelasi sebesar 0,725 serta besamya pengaruh kepribadian ditentukan sebesar 52,56\%, sisanya ditentukan oleh factor lain.

2. Terdapat hubungan signifikan secara parsial antara faktor lingkungan terhadap intensi kewirausahaan santri putri dengan nilai korelasi sebesar 0,233 serta 
besarnya pengaruh factor lingkungan ditentukan sebesar 5,429 \%, sisanya ditentukan oleh factor lain.

3. Terdapat hubungan yang signifikan secara parsial antara motivasi terhadap intensi kewirausahaan santri putri dengan nilai korelasi sebesar 0,440 serta besarnya pengaruh motivasi ditentukan sebesar 19,36\%, sisanya ditentukan oleh factor lain.

4. Terdapat hubungan yang signifikan secara simultan antara kepribadian, faktor lingkungan dan motivasi terhadap intensi kewirausahaan santri putri dengan nilai korelasi sebesar 0,555 serta besarnya pengaruh kepribadian, factor lingkungan dan motivasi secara simultan ditentukan sebesar $30,9 \%$, sisanya ditentukan oleh factor lain.

5. Terdapat koefisien persamaan regersi yang signifikan dengan menggunakan analisis regresi komponen utama dan bentuk persamaan regresinya adalah :

$$
\hat{Y}=0,026+0,062 X_{1}+0,22 X_{2}+0,362 X_{3}
$$

6. Tingkat sensitifitas terbesar intensi kewirausahaan santri putri terdapat pada kepribadian, yaitu sebesar 1,0134 yang dapat diinterpretasikan bahwa bila kepribadian meningkat $1 \%$ akan meningkatkan intensi kewirausahaan santri putri (Y) sebasar 1,042\%.

\section{Implikasi}

Dari hasil analisis diperoleh bahwa kepribadian, factor lingkungan dan motivasi memberikan pengaruh yang positif dan signifikan terhadap intense kewirausahaan santri putri. Hal ini sesuai dengan pendapat Indarti (2008), McClelland, 1961) dan (Gilles dan Rea, 1999) secara umum menjelaskan bahwa intensi kewirausahaan dipengaruhi secara signifikan oleh kepribadian, factor lingkungan dan motivasi dari dalam diri manusia itu sendiri.

\section{Saran}

Karena dalam penelitian ini hanya menggunakan tiga variable yang mempengaruhi intense kewirausahaan, maka akan diketahui secara menyeluruh factor 
lain dari variable yang diteliti sehingga bias diketahui apakah benar factor-faktor diluar penelitian ini juga memberikan pengaruh yang signifikan terhadap intensi kewirausahaan santri putri.

\section{DAFTAR PUSTAKA}

1. Kourilsky, M. L. dan W. B. Walstad, 1998. Entrepreneurship and female youth: knowledge, attitude, gender differences, and educational practices". Journal of Business Venturing 13 (1): 77-88.

2. Gorman, G., D. Hanlon, dan W. King, 1997. "Entrepreneurship education: the Australian perspective for the nineties". Journal of Small Business Education 9: $1-14$.

3. Krueger, N. F. dan A. L. Carsrud, 1993. "Entrepreneurial intentions: applying the theory of planned behavior". Entrepreneurship \& Regional Development 5 (4): 315-330.

4. Choo, S., dan M. Wong, 2006. "Entrepreneurial intention: triggers and barriers to new venture creations in Singapore". Singapore Management Review 28 (2): 47 64.

5. McClelland, D., 1961. The Achieving Society, Princeton, New Jersey: Nostrand.

6. Giles, M., dan A. Rea, 1970. "Career self-efficacy: an application of the theory of planned behavior". Journal of Occupational \& Organizational Psychology 73 (3): 393-399.

7. Kristiansen, S, 2002a. "Individual perception of business contexts: the case of small-scale entrepreneurs in Tanzania". Journal of Developmental Entrepreneurship 7 (3).

8. Katz, J., dan W. Gartner, 1988. "Properties of emerging organizations". Academy of Management Review 13 (3): 429-441.

9. Lee, J., 1997. "The motivation of women entrepreneurs in Singapore". International Journal of Entrepreneurial Behaviour and Research 3 (2): 93-110.

10. McClelland, D., 1971. The Achievement Motive in Economic Growth, in: P. Kilby (ed.) Entrepreneurship and Economic Development, New York The Free Press, 109-123.

11. Bandura, A., 1977. Social Learning Theory, Englewood Cliffs, New Jersey: Prentice Hall.

12. Cromie, S., 2000. "Assessing entrepreneurial inclinations: some approaches and empirical evidence”. European Journal of Work and Organizational Psychology (1): 7-30.

13. Indarti, N., 2004. "Factors affecting entrepreneurial intentions among Indonesian students". Jurnal Ekonomi dan Bisnis 19 (1): 57-70. 
14. Syah, Muhibbin. 2002. Psikologi Pendidikan: Dengan Pendekatan Baru. Bandung :Rosdakarya.

15. Indarti (2008). Intensi Kewirausahaan Mahasiswa: Studi Perbandingan Antara Indonesia, Jepang dan Norwegia, Jurnal Ekonomika dan Bisnis Indonesia, Vol. 23, No. 4, Oktober 2008

16. Peranan Universitas Dalam Memotivasi Sarjana Menjadi Young Entrepreneurs (Seri Penelitian Kewirausahaan) Jurnal Manajemen \& Kewirausahaan Vol. 5, No. 2, September 2003: $97-111$

17. Scapinello, K. F., 1989. "Enhancing differences in the achievement attributions of high and low motivation groups". Journal of Social Psychology 129 (3): 357-363.

18. Sengupta, S. K. dan S. K. Debnath, 1994. "Need for achievement and entrepreneurial success: a study of entrepreneurs in two rural industries in West Bengal". TheJournal of Entrepreneurship 3 (2): 191-204.

19. Schwartz, S. H. (1994). Are There Universal Aspect in the Structure and content of Human Value? Journal of Social Issue, 50: $19-46$.

20. Steel, D., 1994. "Changing the institutional and policy environment for small enterprise development in Africa". Small Enterprise Development 5 (2): 4-9.

21. Kristiansen, S., B. Furuholt, dan F. Wahid, 2003. "Internet cafe entrepreneurs: pioneers in information dissemination in Indonesia". The International Journal of Entrepreneurship and Innovation 4 (4): 251-263.

22. Kristiansen, S, 2002b. "Competition and knowledge in Javanese rural business'. Singapore Journal of Tropical Geography 23 (1): 52-70.

23. Mazzarol, T., T. Volery, N. Doss, dan V. Thein, 1999. "Factors influencing small business start-ups". International Journal of Entrepreneurial Behaviour and Research 5 (2): 48-63.

24. Aldrich, H., dan C. Zimmer, 1986. 'Entrepreneurship through Social Network', in D. L. Sexton and R. W. Smilor (eds.) The Art and Science of Entrepreneurship, Cambridge: Ballinger Publishing, 3-25.

25. Riduwan. 2005. Belajar Mudah Penelitian. Bandung : Alfabeta

26. Hamalik, Oemar. 2004. Psikologi Belajar dan Mengajar. Bandung : Sinar baru Algensido

27. Bungin, Burhan (2009). Metodologi Penelitian Kuantitatif, Penerbit Kencana Prenada Media Grup, Jakarta, hal 105. 